九州大学学術情報リポジトリ

Kyushu University Institutional Repository

\title{
A REVISION OF THE GENUS STENA2MIMA OF JAPAN (Hym., Formicidae, Myrmicinae)
}

Yasumatsu, Keizo

Murakami, Yozo

https://doi.org/10.5109/2342

出版情報: ESAKIA. 1, pp.27-31，1960-01-20. Hikosan biological laboratory, Faculty of Agriculture, Kyushu University バージョン :

権利関係 : 
EsaKIa No. 1

JANUARY 20, 1960

\title{
A REVISION OF THE GENUS STENAMMA OF JAPAN* \\ (Hym., Formicidae, Myrmicinae)
}

\author{
BY \\ Keizô Yasumatsu and Yôzô Murakami
}

The genus Stenamma has been represented by only a single species, owstoni Wheeler, in Eastern Asia. It should be noted that no specimens have yet been recorded from that area since the original description of that species in 1906 and its single record from S. Kansu, China, in 1935. As Dr. Marion R. Smith pointed out, the restricted habitats and drabness of color of the workers may be responsible for the infrequent collecting of Stenamma in spite of the extensive collections of ants made in Japan by many able Myrmecologists. The primitive status of our knowledge on the Stenamma fauna in Eastern Asia makes every collection from that area of great scientific value.

The collections made by Dr. Sakagami in Hokkaido in 1957, by Mr. Takechi in Shikoku in 1954 and 1955, and by the author's collaborators and the senior author in Kyushu during 1930 to 1957 are of particular interest, since the species of Stenamma were collected from localities from which no record of the genus previously existed.

This is a preliminary revision of the species of the genus Stenamma of Japan. The senior author is greatly obliged to Dr. William L. Brown, Jr. of the Museum of Comparative Zoology, Cambridge, for permitting him to examine the type specimen of Stenamma owstoni Wheeler, as well as for his kind advice in the course of the present study. The senior author's thanks are also due to Dr. Marion R. Smith of the U. S. National Museum, Washington, D. C., for his kindness while he was in the museum in 1956. The authors are indebted to Professor T. Ishihara and Mr. F. Takechi of Ehime University, Matsuyama, and Professor S. Sakagami of Hokkaido University for making possible the study of their collections.

* Contribution Ser. 2, No. 56, Entomological Laboratory, Kyushu University, Fukuoka.

Contribution Ser. 2, No. 9, Hikosan Biological Laboratory, Kyushu University, Hikosan. 
Key to the species of Stenamma

Worker

Eye very small, its greatest diameter distinctly shorter than the second segment of antennal club or about as long as the eighth antennal segment. ..... ....................... nipponense sp. nov. Eye.comparatively large, its greatest diameter about as long as the second segment of antennal club .............. owstoni Wheeler

\section{Female}

Ocelli arranged in an acute-angled triangle. Distance between the upper end of the frontal area and anterior ocellus much longer than that between the upper end of the frontal area and the anterior margin of clypeus. .....

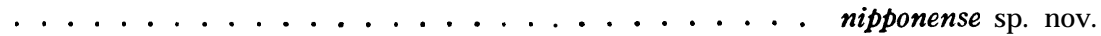
Ocelli arranged in an obtuse-angled triangle. Distance between the upper end of the frontal area and anterior ocellus almost as long as the distance between the upper end of the frontal area and the anterior margin of clypeus. ... ........................ owstoni Wheeler

\section{Stenamma nipponense sp. nov.}

Worker. Antennal segment 3 through 7 wider than long; 8 as wide as long, shorter than the two preceding segments taken together; last segment of antennal club slightly but distinctly shorter than the combined lengths of the three preceding segments. Eye very small, oval, approximately $0.08 \mathrm{~mm}$. and four ommatidia in its greatest diameter, its greatest diameter distinctly shorter than the second segment of antennal club or about as long as antennal segment 8.

Thorax seen from above slender, $1.3 \mathrm{~mm}$. in length from the anterior margin of the pronotal collar to the junction with petiole, widest through humeral angles and narrowest through propodeum, with pronounced humeral angles; seen in profile, metanotal impression moderately well developed, approximately $0.08 \mathrm{~mm}$. in length and $0.03 \mathrm{~mm}$. in depth, base of propodeum distinctly sloping to meet the declivity, propodeal teeth being $0.08 \mathrm{~mm}$. in length or less and more acute ; petiole very slender and claviform, seen from above, with the sides almost straight, very slightly diverging posteriorly, seen in profile, its node is subangular, approximately $0.51 \mathrm{~mm}$. in length, length : depth : width $=24$ : $10: 8$; postpetiole also slender, longer than wide, much narrowed anteriorly than posteriorly, length : depth : width $=14: 9: 10$; postpetiolar node very slightly larger than petiolar node and almost similarly convex both anterior half and posterior half.

Gaster with the apex slightly more acute than the base, the latter lacking humeral angles.

Frontal area smooth and shining. Front with posteriorly diverging, longitudinal striae, remainder of head reticulate with punctate interspaces. Thorax very 
coarsely, irregularly rugulose-reticulate, rugulae on the sides of the posterior third having a longitudinal trend. Petiolar and postpetiolar nodes somewhat finely punctulate except for their surface which are nearly shining. Propodeal declivity and gaster smooth and shining. Base of the first gastric segment with vestigial longitudinal short rugae.
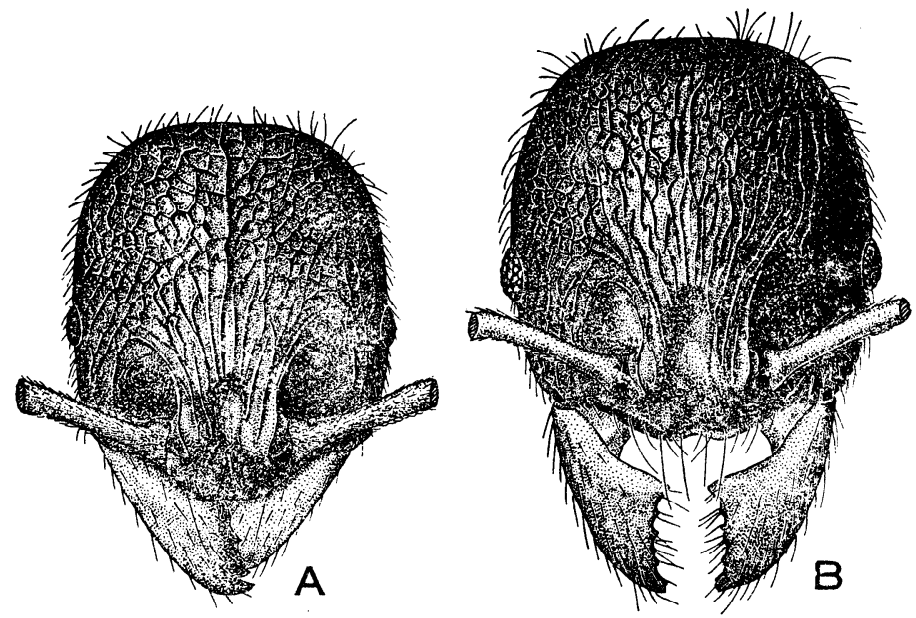

Fig. 1. Head of the worker of Japanese species of Stenamma.

A, S. nipponense sp. nov. B, S. owstoni Wheeler.

Body dark brownish, appendages lighter in color.

Hair pale greyish, erect or suberect, those on head and thorax rather dense, those on abdomen sparse, on legs and scapes depressed or subdepressed.

Body length about $3.5 \mathrm{~mm}$.

Deälate female. Similar to the worker except as described below. Ocelli arranged in an obtuse-angled triangle, distance between anterior ocellus and the upper end of frontal area as long as the distance between the upper end of the frontal area and the anterior margin of clypeus, greatest diameter of eye approximately $0.21 \mathrm{~mm}$., with about 13 ommatidia, as long as malar space. Distance between the propodeal spines as long as that between the base of propodeal spines and the apex of alitrunk. Frontal area and interspinal area of propodeum smooth and shining. Pronotum coarsely rugulose-reticulate, at the sides the rugulae somewhat transverse ; the longitudinal rugulae on mesonotum somewhat convergent towards the middle of the anterior border; scutellum more finely sculptured than mesonotum; area above propodeal spines irregularly rugulose ; upper portion of mesepisternum with about four longitudinal rugulae, boundary between the upper and lower portions deeply, broadly furrowed and costate, metapleura and the sides of propodeum with longitudinal rugulae, side of anterior coxae transversely rugulose. Petiole and postpetiole punctulate and 
the former with a few longitudinal rugulae on the sides and posterior surface of the petiolar node showing traces of rugulae.

Body length about $4.2 \mathrm{~mm}$.

Original localities.-Hokkaido (Oshoro), Shikoku (Saragamine) and Kyushu (Hikosan), Japan.

Holotype.-Worker, 28. vii. 1939, Hikosan (Mt. Hiko), Fukuoka Prefecture, Kyushu, K. Yasumatsu leg.

Paratypes.-Deälated female, 23. ii. 1935, Saragamine (Mt. Sara), Ehime Prefecture, Shikoku, Morikawa leg. ; one worker, 28. vii. 1939, Hikosan, Yasumatsu leg.; one worker, 4. vi. 1941, Hikosan, Yasumatsu leg.; one worker, 15. v. 1955, Saragamine, F. Takechi leg. ; 5 workers, 13. v. 1957, Oshoro, Hokkaido, S. Sakagami leg. One paratype will be deposited in the collection of the Museum of Comparative Zoölogy at Harvard College, Cambridge, one paratype in the collection of the U. S. National Museum, Washington, D. C., and one paratype in the collection of Ehime University, Matsuyama.

\section{Stenamma owstoni Wheeler}

1906 Stenamma owstoni Wheeler, Bull. Amer. Mus. Nat. Hist., 22: 314, worker (Yamanaka, Suruga, at an altitude of $2000 \mathrm{ft}$. "in rotten wood," Japan -Honshu).

1928 Stenamma owstoni Wheeler, Bol. Lab. zool., Portici, 21: 124 (Japan listed).

1935? Stenamma owstoni Stitz, Arkiv för Zoologi, 27A, 11: 2, worker (S. Kansu, China).

1951 Stenam ma ows toni Chapman et Capco, Check list of the ants (Hymeno. ptera: Formicidae) of Asia, p. 153 (Listed from Japan only).

This species is closely related to the preceding one. The following is the main difference.

Worker. Antenna7 segment 3 through 6 wider than long; 7 and 8 about as wide aslong; 8 almost as long as 7; last segment of antennal club slightly but distinctly shorter than the combined lengths of the three preceding segments. Eye comparatively large, approximately $0.1 \mathrm{~mm}$. and seven ommatidia in its greatest diameter, its greatest diameter almost as long as the second segment of antennal club.

Thorax, seen from above, slender, $1.28 \mathrm{~mm}$. in length from the anterior margin of the pronotal collar to the junction with the petiole; seen in profile, metanotal impression moderately well developed, approximately $0.06 \mathrm{~mm}$. in length and $0.04 \mathrm{~mm}$. in depth; petiole- length : depth: width $=23: 11: 8$; postpetiole-length : depth : width $=17: 11: 12$.

Body length about $4.0 \mathrm{~mm}$.

Deälated female. Ocelli arranged in an acute-angled triangle, distance between anterior ocellus and the upper end of the frontal area much longer than the distance between the upper end of the frontal area and the anterior margin of clypeus or twice as long as the distance between anterior ocellus and vertex. 
Greatest diameter of eye approximately $0.23 \mathrm{~mm}$. and with about 14 ommatidia. Distance between propodeal spines shorter than the distance between the base of the propodeal spine and the apex of alitrunk. Boundary between the upper and lower portions of mesepisternum not so deeply pronounced and narrow.

Dorsum and the sides of petiole with several longitudinal rugulae, the sides and posterior half of postpetiolar node also with some longitudinal rugulae.

Body length about $4.5 \mathrm{~mm}$.

Distribution.-Japan (Honshu, Shikoku and Kyushu) and China (S. Kansu). Specimen examined.-One deälated female, 2 workers, 1. ii. Hirao, Fukuoka, Esaki et al. leg.; 11 workers and one deälated female, 4. ii. 1957, Hirao, T. Saigusa leg. ; 2 workers, 10. iii. 1957, Mizunashi, Fukuoka Prefecture, K. Morimoto leg.; 7 workers, 16. iii. 1957, Suwa Temple, Nagasaki, H. Kamiya et Y. Nonaka leg. ; one worker, 30. xii. 1954, Mt. Sara, Ehime Prefecture, F. Takechi leg.; one worker, 23. ii. 1955, Mt. Sara, K. Morikawa leg.

\section{Explanation of Plate 7}

Fig. 1. Stenamma nipponense Yasumatsu et Murakami, sp. nov., worker.

Fig. 2. Stenamma owstoni Wheeler, worker.

Fig. 3. Stenamma owstoni Wheeler, deälated female. 


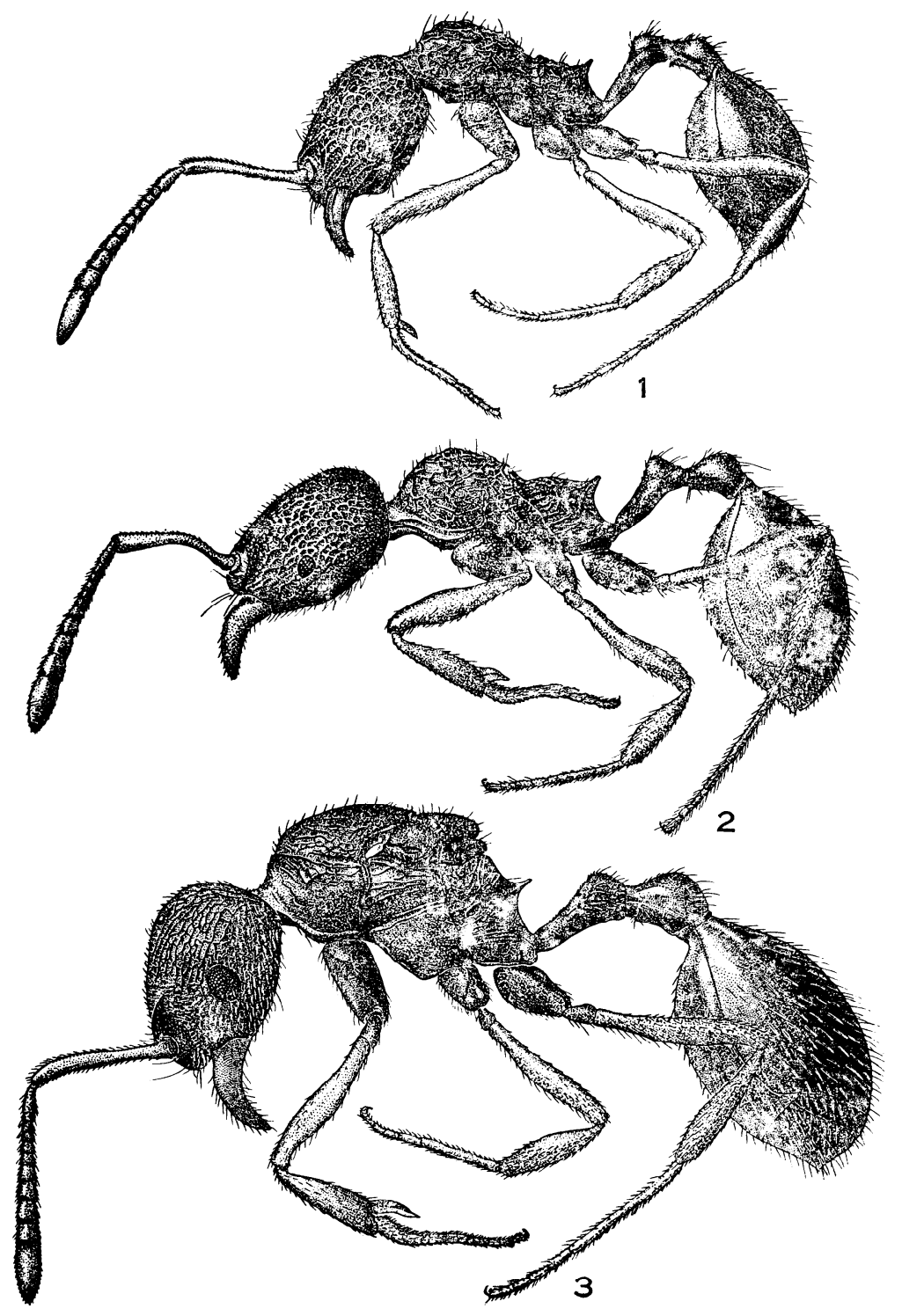

